\title{
Spatial distribution and nutritional requirements of the endosymbiont- bearing bivalve Loripes lacteus (sensu Poli, 1791) in a Mediterranean Nanozostera noltii (Hornemann) meadow
}

\author{
Francesca Rossi ${ }^{a, *}$, Elodie Colao ${ }^{a}$, Maria Jose Martinez ${ }^{c}$, Judith C. Klein ${ }^{a, d}$, Frédérique Carcaillet ${ }^{a}$, \\ Myriam D. Callier ${ }^{\mathrm{a}, \mathrm{b}}$, Rutger de Wit ${ }^{\mathrm{a}}$, Audrey Caro ${ }^{\mathrm{a}}$
}

\author{
a Ecologie des Systèmes marins côtiers (Ecosym), UMR 5119, Université Montpellier 2, CNRS, IRD, Ifremer, \\ Université Montpellier 1, F-34095 Montpellier, France \\ b IFREMER, Département Ressources Biologiques et Environnement, UMR 5119, Station de Palavas, F-34250 \\ Palavas-les-Flots, France \\ ${ }^{\mathrm{C}}$ Laboratorio de Zoologia, Universidad Pablo de Olavide, 41013 Sevilla, Spain \\ d Leibniz-Center for Tropical Marine Ecology, Fahrenheitstr. 6, 28359 Bremen, Germany \\ *: Corresponding author: Francesca Rossi, tel.: + 33467143371 ; fax: + 33467143719 ; \\ email address : francesca.rossi@univ-montp2.fr
}

\begin{abstract}
:
Sulphur-oxidising endosymbiont-bearing bivalves often inhabit seagrass meadows, where they can control sulphide levels and variably contribute to carbon cycling, by feeding on endosymbiotic bacteria and/or on particulate organic matter from the water column. The patterns of variability in their feeding mode and their spatial distribution within the seagrass meadows are however poorly studied. Seagrass beds form naturally patchy habitats with seagrass-sand edges that may have variable effects on different organisms. The present study aims at understanding differences in feeding mode and abundance of the endosymbiontbearing bivalve Loripes lacteus (sensu Poli, 1791) as well as the physiological conditions of its endosymbiotic populations between edge and inner portion of meadows of the eelgrass Nanozostera noltii (Hornemann). In July 2010, Loripes specimens were sampled in 4 eelgrass patches at 2 different locations in the Thau lagoon, South of France. There was a clear negative edge effect on the abundance of small individuals of Loripes, while large individuals were homogeneously distributed between edge and inner part of the meadow. Although Loripes isotopic signatures $\left(\delta^{13} \mathrm{C}\right.$ and $\left.\delta^{15} \mathrm{~N}\right)$ were always closer to those of its symbiotic bacteria than to those of suspension-feeding bivalves, eelgrass edge enhanced mixotrophic behaviour of small animals, which assimilated less bacterial carbon and nitrogen at the edge than in the inner part of the eelgrass meadow. No differences related to eelgrass edges were instead found for the bacterial populations harboured by Loripes. Rather, flow cytometry revealed large variability at small spatial scales. Although bacteria were always important for the nutrition of Loripes, these findings showed that seagrass edges may contribute to regulate feeding mode and population structure of Loripes, which may have implications for seagrass functioning.
\end{abstract}

\section{Highlights}

We studied distribution and diet of an endosymbiont-bearing bivalve in seagrasses. Endosymbiont bacteria are a primary source of carbon and nitrogen for the host. There was a clear seagrass edge effect on population structure and feeding mode. $\rightarrow$ There were few small individuals at edges, which assimilated more heterotrophic food. Edge effects may modify the trophic pathway for seagrass functioning.

Keywords: Bivalve ; Food web ; Mediterranean ; Seagrass ; Stable isotopes ; Symbiosis 


\section{Introduction}

Several macrofauna species are known to live in association with chemoautotrophic bacteria that enzymatically oxidize sulphides (Cavanaugh, 1983) or methane (Fisher, 1990) and provide energy to fix dissolved carbon dioxide (Felbeck et al., 1981). Symbiont-bearing organisms are common to different ecosystems, ranging from deep-sea hydrothermal vents to shallow coastal waters (Cavanaugh et al., 2006, McLeod et al., 2010). In this association, the eukaryote host favours bacterial chemosynthesis by facilitating the supply of sulphide or methane, $\mathrm{CO}_{2}$ and oxygen. In turn, endosymbiotic bacteria represent alternative food sources for the host, which thus becomes capable of occupying unexplored trophic niches (Stewaert et al., 2005). This symbiosis can effectively change sediment biogeochemistry and ecosystem functioning (Reynolds et al., 2007), by reducing toxic sulphide levels (van der Heide, 2012) and converting $\mathrm{CO}_{2}$ directly into consumer biomass, available to predators (McLeod and Wing, 2007, 2009).

Endosymbiont-bearing macrofauna may sometimes vary their feeding behaviour during reproduction, host development and following environmental changes (Spiro et al., 1986, Pile and Young, 1999), thereby modifying their impact on $\mathrm{CO}_{2}$ transfer to the food web and sediment toxicity. Nutritional requirements of the host and its size may also modify abundance, reproduction and activity of the symbiotic populations, by regulating sulphide supply and the amount of $\mathrm{CO}_{2}$ fixed (Stewart et al., 2005, Dufour and Felbeck, 2006, Caro et al., 2009).

The bivalves of the family Lucinidae harbour sulphide-oxidizing bacteria in the gills, where they transport oxygen, $\mathrm{CO}_{2}$, and sulphide using their extremely extensible foot (Stewart et al., 2005, van der Heide et al., 2012). These bivalves are known to be mixotrophs since they can rely on the energy and nutrients derived either from particulate food or endosymbiotic bacteria (Schweimanns and Felbeck, 1985, Herry et al., 1989, Johnson and Fernandez, 2001, Duplessis et al., 2004, Taylor and Glover, 2006). Shifts in feeding mode can occur following changes in food supply (van Gils et al., 2012), during reproduction or individual development in relation to their energetic demand, since heterotroph suspended food is more energetically rewarding than bacteria (Le Pennec and Beninger, 2000).

Lucinid bivalves and their sulphide-oxidizing endosymbiotic bacteria often occur in seagrass meadows, where they occupy the anoxic sediment layer in proximity to the root zone, where sulphide production rates are high (van der Heide et al., 2012). So far, patterns of distributions of lucinid bivalves and their changes in feeding behaviour are poorly studied in seagrasses (van der Heide et al., 2012). This information is however important for seagrass conservation and management since the association of lucinid bivalves and sulphide-oxidising bacteria can contribute to detoxifying the sediment from sulphides (van der Heide et al., 2012) and changing carbon sequestration and recycling (Johnson et al., 2002).

Seagrass landscapes are often spatially heterogeneous and consist of variably extended fragmented seagrass patches interspersed in a more uniform substrate such as sand or mud (Heck et al., 2003, Bostrom et al., 2006). The edges between two habitats are transitional zones, where there can be dramatic changes in environmental variables and biological processes (Ries et al., 2004, Carroll et al., 2012). Seagrass edges can slow hydrodynamics down, thereby increasing passive larval settlement and availability of suspended food particles. Predation pressure can also increase considerably because several animals seeking refuge within seagrass meadows find prey more easily accessible at 
the interface between seagrass and bare sediment than in the inner part of the seagrass (Bologna and Heck, 2002, Tanner, 2005, Bostrom et al., 2006, Carroll et al., 2012).

This paper aims at quantifying the spatial patterns of distribution and the population structure of the endosymbiont-bearing Lucinidae bivalve Loripes lacteus (sensu Poli, 1791), its feeding mode and the physiological conditions of its symbiont populations within patches of the eelgrass Nanozostera noltii (Hornemann). L. lacteus is considered a mixotrophic species (Johnson et al., 2002, Carlier et al., 2009), often abundant in temperate and subtropical coastal sediments occupied by seagrasses and macrophyte detritus (Honkoop et al., 2008, van der Heide et al., 2012). This paper specifically tested whether there were differences between the inner part and the edge of eelgrass patches in (i) the population structure of L. lacteus; (ii) Loripes isotopic signatures $\left(\delta^{13} \mathrm{C}\right.$ and $\left.\delta^{15} \mathrm{~N}\right)$ in relation to animal shell size and (iii) symbiotic bacterial populations, through flow cytometry.

Stable isotopes have proven to be a useful tool to study chemoautotrophy in marine invertebratebacteria symbioses (Spiro et al., 1986, Dando and Spiro, 1993, Pile and Young, 1999) and they continue to be useful in assessing mixotrophic behaviour, symbiont metabolism and tracking energy and carbon transfer in chemosynthetic symbioses (e.g. Levin and Michener, 2002, Scott, 2005). In addition, flow cytometry can be strategic to identify differences in bacterial abundance, reproduction and activity (Caro et al, 2007, 2009). Coupling isotope and flow cytometry studies can therefore contribute to elucidate reciprocal effects between endosymbiont bacteria and their host.

\section{Material and Methods}

\subsection{Study area and sampling}

Sampling was done at the Bouzigues shore $\left(43^{\circ} 27^{\prime} 02.9^{\prime \prime} \mathrm{N} 003^{\circ} 39^{\prime} 15.5^{\prime \prime} \mathrm{E}\right)$ in the Thau lagoon (south of France). Groynes run perpendicular to the shore for $50 \mathrm{~m}$ and divide the area into subtidal locations some hundred meters wide. The entire shore is sheltered from winds and currents, except from south winds that blow uniformly into the shore. The area is also interested by shellfish cultivation which stands $300 \mathrm{~m}$ far from the shoreline. Seagrass meadows are characterized by well developed $N$. noltii patches interspersed with bare sediment. $N$. noltii is present exclusively from 0 to $1 \mathrm{~m}$ depth and replaced by Zostera marina (L.) in deeper waters. In this area L. lacteus was one of the dominant bivalves inhabiting the seagrass, but only few individuals occurred in bare sediment (Rossi F., unpublished data).

On July 5 and 6, 2010 two $250 \mathrm{~m}^{2}$ wide Nanozostera noltii patches were sampled at each of two locations (hereafter location 1 and 2) to the depth of 0.4-0.8 $\mathrm{m}$. The edges of these patches were adjacent to bare sediment at 3 out of 4 sides. The side adjacent to the groynes was not sampled. Five $1 \mathrm{~m}^{2}$ plots were randomly chosen in the inner part and at the edge of each of the four patches. Edge and inner part were at least $5 \mathrm{~m}$ apart. At each plot, percentage eelgrass cover was estimated visually using $1 \mathrm{~m}^{2}$ quadrats divided into a uniform grid of 100 segments (i.e. each cell in the grid had dimensions of $10 \times 10 \mathrm{~cm}$ and represented $1 \%$ coverage in the sampling unit). For each plot, one sediment core (12 cm inner diameter, i. d.) was sampled to the depth of $10 \mathrm{~cm}$ for collecting animals. 


\subsection{Laboratory analyses}

The sediment cores were sieved through a sieve mesh of $250 \mu \mathrm{m}$ and all specimens of $L$. lacteus collected the same day of sampling. For each replicate core, the shell length of all L. lacteus specimens was measured using a calliper with $0.1 \mathrm{~mm}$ resolution. Each animal was dissected to remove the foot muscle and the gills. Individuals of the bivalves Polititapes (Venerupis) aurea (Gmelin, 1791) and Cerastoderma glaucum (Bruguière, 1789) were also collected, counted and dissected to collect the foot muscle. Gills were used for analysing endosymbiotic bacteria for isotopic signatures and physiological characteristics by flow cytometry. Only gills that appeared well developed and white were analysed since this appearance indicates the presence of vigorous populations of sulphuroxidizing bacteria (Hentschel et al., 2000). The foot muscles were instead used for isotope analyses of all bivalves.

For isotope analyses $\left(\delta^{13} \mathrm{C}\right.$ and $\left.\delta^{15} \mathrm{~N}\right)$, the foot muscles and the gill tissues were freeze-dried.

The foot muscles of $L$. lacteus were analysed separately for each shell length, while those of the other two bivalves were grouped together. The isotopic signatures of $V$. aurea and $C$. glaucum were used as a proxy for particulate organic carbon and nitrogen because these bivalves are benthic suspension feeders and acquire their food through their siphon at the sediment-water interface (Bachelet et al., 2000, Rossi et al., 2004). When feeding on heterotrophic food, L. lacteus acquires food through a similar suspension feeding mode. Choosing to use these animals as a proxy rather than sampling particulate organic matter allowed to avoid correcting data for fractionation and to have values that integrated food sources through time.

Gill isotopic values estimated the isotopic signature of endosymbiotic bacteria. We were unable to isolate endosymbiotic bacteria for isotope analyses. Isotope signature of bacteria was estimated by mean of a mass-weighted model (Fry, 2008), assuming that bacteriocytes (e.g. cells containing bacteria) represented $55 \%$ of gill weight (Johnson and Fernandez, 2001). The mass-weighted model was thus:

$\left(m_{B}+m_{G}\right) \delta X_{B+G}=m_{B} \delta X_{B}+m_{G} \delta X_{G} \quad$ and $m_{B}+m_{G}=1$

where $\delta X_{B+G}$ is the isotope value of the gills with bacteria, $\delta X_{B}$ is the isotopic value of the bacteria and $\delta X_{G}$ is the isotope value of host tissues (gills in this case); $m_{B}$ and $m_{G}$ are the bacterial and gill biomasses, respectively. They were estimated as 0.45 and 0.55 , respectively.

The estimates varied between -30 and $-28 \%$ for $\delta^{13} \mathrm{C}$ and between -4 and $2 \%$ for $\delta^{15} \mathrm{~N}$. These estimates were in the range of variability found in the literature (Stewart et al., 2005, Levin and Michener, 2002, Cavanaugh et al., 2006), indicating they were good estimates of actual bacterial values.

The carbon and nitrogen isotopic composition of the samples was determined using a Fisons elemental analyzer coupled on line via a Finningan conflo 2 interface to a Finningan delta $\mathrm{S}$ mass spectrometer. The carbon and nitrogen isotope ratios are expressed in the delta notation $\delta^{13} \mathrm{C}$ and $\delta^{15} \mathrm{~N}$, where $\delta X=([$ Rsample /Rreference $] \times 1) \times 10^{3}$. Results are referred to Vienna PDB for $\mathrm{C}$ and to atmospheric nitrogen for $\mathrm{N}$ and expressed in units of \%o.

For flow cytometry, gill tissues were extracted from individuals $>3 \mathrm{~mm}$ to allow a sufficient quantity of material to run the analyses. A total of 71 gills were analysed. Endosymbiotic bacteria were extracted 
after crushing gill tissues in $2 \mathrm{ml}$ of filtered $(0,2 \mu \mathrm{m})$ natural seawater (35ppt) using a hand held Dounce homogenizer to obtain a symbiotic suspension. An amount of $1.6 \mathrm{ml}$ of this suspension was fixed with $80 \mu \mathrm{l}$ of formaldehyde (1\% final concentration) and immediately stored at $-80^{\circ} \mathrm{C}$. The symbiotic suspension was thawed and diluted (1/100) in saline water (30ppt $\mathrm{NaCl})$. Nucleic acids were stained for $15 \mathrm{~min}$ in the dark at $4^{\circ} \mathrm{C}$ with SYBR Green I (Molecular Probes, Eugene, Oregon) according to the method described by Marie et al. (1997) (1:10000 vol/vol). Symbiont cells were analysed with a FACSCalibur flow cytometer (Becton Dickinson) equipped with a blue $(488 \mathrm{~nm})$ argon laser. The green fluorescence (FL1) emitted by Sybr green stained bacteria was used as a proxy for nucleic acid content, while the cells side scatter (SSC) was used as a proxy for relative cell size and for intracellular sulphur content and indicated the bacterial activity (Troussellier et al., 1999, Caro et al., 2007). FL1 and SSC parameters were collected on a logarithmic scale. As internal standard for normalization of symbiont fluorescence emission, $1 \mu \mathrm{m}$ and $2 \mu \mathrm{m}$-yellow green fluorescent cytometry beads (Polysciences, INC) were added to the samples. The sheath fluid ( $\mathrm{NaCl}$ solution, 30ppt) was filtered through $0.2 \mu \mathrm{m}$-pore-size membrane. Analyses were run at low speed (around $18 \mu \mathrm{min}^{-1}$ ) and acquisition was done for 2 min corresponding to a total of 25,000 to 35,000 detected cells. The normalised average values for each of these parameters (SSC and FL1) were calculated from the cytograms through the CellQuest software program and analysed statistically. Symbiotic suspension could not be purified from cellular debris. Nevertheless, in the dot-plot representation of the cytogram the symbiotic population appeared as a cloud of dots clearly separated from the background due to cell debris (Caro et al., 2007, 2009).

\subsection{Statistical analyses}

The population structure of Loripes lacteus was studied by comparing the size frequency distribution between the edge and the inner part of the eelgrass meadow using the Kolmogoroff-Smirnoff test. $A$ posteriori, animals were carefully divided into 3 size classes based on their frequency distribution: (i) size class I: individuals $\leq 3 \mathrm{~mm}$; size class II: individuals $>3$ and $<10 \mathrm{~mm}$; size-class III: individuals $\geq$ $10 \mathrm{~mm}$.

A 2 way- analysis of covariance model (ANCOVA) with location (random, 2 levels) and position (orthogonal, fixed, 2 levels) as factors was used to detect differences among positions (inner part vs. edge) in L. lacteus $\delta^{13} \mathrm{C}$ and $\delta^{15} \mathrm{~N}$ values as a function of shell size, which was the co-variate. Before the analyses, the significance of linear correlations between $\delta^{13} \mathrm{C}$ or $\delta^{15} \mathrm{~N}$ and shell size were tested separately for each combination of location and position. If correlations were significant $(p<0.05)$ for all combinations, the homogeneity of $b$ (as the slopes of linear regression) was tested. Homogeneity of variance from regression was tested using Cochran's $C$ test (Underwood, 1997, Crawley, 2007).

A 3 way mixed model of analyses of variance (ANOVA) with location, position and patch (nested in location, 2 levels) as factors, was used to test for differences between positions (inner part vs. edge) in abundance, $\delta^{13} \mathrm{C}$ and $\delta^{15} \mathrm{~N}$ of the host and in symbiont parameters SSC or FL1 at each size class separately. For abundance and isotope analyses 5 replicate cores were used at each size class. For FL1 and SSC, analyses were done for size classes II and III and 3 replicate individuals were used to balance the ANOVA tests. Pooling of the interaction terms was done when F-ratio was $>0.25$. Before running the analyses, Cochran test was done for homogeneity of residual variance. Data were transformed to homogenise residual variance as indicated in the Results section. When significant differences in the interactions occurred, SNK test $(P=0.05)$ was used as a posteriori multiple comparison for testing for differences among positions at each location or patch. 
The trophic significance of bacterial nitrogen and carbon for host diet at each size class was first visualized using a dual-isotope graph, where mean $( \pm S E) \delta^{13} \mathrm{C}$ were plotted vs mean $( \pm S E) \delta^{15} \mathrm{~N}$ for host size classes, for the bivalves $V$. aurea and $C$. glaucum as well as for the endosymbiotic bacteria, which were corrected for fractionation based on 1 trophic level difference ( 1 and $3 \%$ for $\delta^{13} \mathrm{C}$ and $\delta^{15} \mathrm{~N}$, respectively, see Cavanaugh et al., 2006, Fry, 2008). Therefore, all isotope values in the dualgraph referred to estimates of isotope signatures for first-order consumers feeding on particulate organic matter or endosymbiont bacteria. Based on these estimates, the percentage bacterial contribution to host diet was calculated using the two-sources mixed model (Fry, 2008), independently for carbon and nitrogen. It was assumed that the host could derive food from two sources, the endosymbiotic bacteria or the particulate organic matter, similarly to other suspension feeder bivalves (e.g. C. glaucum and V. aurea):

$\delta X_{H}=f_{B} \delta X_{B \mid F}+f_{S F} \delta X_{S F} \quad$ and $f_{B \mid F}+f_{S F}=1$

where $\delta X_{H}$ is the isotope value of the host, $\delta X_{B \mid F}$ is the isotope value for bacteria corrected for fractionation and $\delta X_{S F}$ is the isotope value for suspension feeding bivalves; $f$ represents the fraction of assimilated carbon or nitrogen. The estimated fraction $f$ was expressed as percentage. Statistical tests were not done on these estimates because they were done on $\delta^{13} \mathrm{C}$ and $\delta^{15} \mathrm{~N}$ raw data.

\section{Results}

\subsection{Population structure of the host}

The population structure of $L$. lacteus varied between the inner part and the edge of the eelgrass patches (Kolmogoroff-Smirnoff test: $D=0.18, P<0.05$ ), which were characterised by different eelgrass cover (80-100 \% and 65-70\%, respectively). The 3-way ANOVA showed that animals belonging to size-classes I and II ( $\leq 3 \mathrm{~mm}$ and $3<\mathrm{x}<10 \mathrm{~mm}$, respectively) were more abundant in the inner part than at the edge (Table 1). There were no differences for the largest animals of size class III ( $\geq 10 \mathrm{~mm}$; Table 1).

\subsection{Isotope signatures of the host}

There was a significant negative linear correlation between the shell length of $L$. lacteus and the $\delta^{15} \mathrm{~N}$ or $\delta^{13} \mathrm{C}$ isotopic signature of the foot muscles at each position (inner part and edge) and location (location 1 and 2), except for $\delta^{15} \mathrm{~N}$ at the edge of location 2 (Fig. 1). The 2-way ANCOVA was therefore done only for $\delta^{13} \mathrm{C}$ values. This analysis showed heterogeneous slopes between the edge and the inner part $(P<0.05$ for effects interaction of Size $\times$ Position and Size $\times$ Location $\times$ Position). The slopes were steeper for the edge than for the inner part (Fig. 1a).

The 3-way ANOVA evidenced differences between positions for $\delta^{13} \mathrm{C}$ values of size class I and II and for $\delta^{15} \mathrm{~N}$ of size-class I (Table 2). Moreover, there was a significant Location $\times$ Position interaction for $\delta^{15} \mathrm{~N}$ values of size class II (Table 2). At both locations, animals were more ${ }^{15} \mathrm{~N}$-depleted in the inner part than at the edge (SNK test, $\mathrm{P}<0.05)$.

\subsection{Dual-isotope plot and mixing model}


The dual-isotope graph (Fig. 2) showed that the isotopic signatures of L. lacteus foot muscle were closer to those of bacteria, as corrected for fractionation (see Materials and Methods) than to the isotopic signatures typical of bivalves that suspension-feed on particulate matter (C. glaucum and $V$. aurea). The graph also evidenced that small specimens (size classes I and II) at the edge of the seagrass patches were closer to the isotopic signatures of suspension feeders than all size classes in the inner part. The mixing model estimated that there was 5 to $10 \%$ difference between the bacterial carbon assimilated by the small individuals inhabiting the edges of the eelgrass patches as compared to that assimilated by individuals inhabiting the inner part of the patches (Fig. 3). These differences were up to $30 \%$ when considering bacterial nitrogen (Fig. 3).

\subsection{Flow cytometric characteristics of symbiotic populations}

In the cytogram of Fig. 4a, the symbiotic bacterial populations appeared as a cloud of dots that clearly separated from the background noise, especially for the nucleic acid (FL1) content. In other words, the FL1 values were higher than the background noise, clearly indicating that our method could distinguish bacterial populations (Caro et al., 2007, 2009). The cytogram also indicated that the symbiotic populations isolated from the same host showed wide values of SSC and FL1, indicating heterogeneous content of relative size (SSC) and genomic content (FL1) in the population. The normalised average FL1 and SSC did not significantly differ among the positions within the seagrass bed (edge vs inner part) at both locations (Fig. 4b). Rather, there were significant differences among locations for the SSC value of size class III $\left(F_{1,2}=805.34, P=0.001\right)$ and significant differences for the position $\times$ patch interaction for both SSC and FL1 of size class II $\left(F_{2,16}=5.11, P=0.02\right.$ for SSC and $F_{2,16}$ $=3.77 P=0.04$ for FL1), but the SNK test did not identify any effect of position.

\section{Discussion}

In a fragmented landscape, habitat edges are transitional areas that provide specific environmental conditions, often enhancing species abundance and diversity (Bell et al., 2001). Nonetheless, edge effects can vary considerably among species and following the environmental context (Ries et al., 2004, Bostrom et al., 2006). Differential abundance patterns related to seagrass edges were, for instance, found for the Solemyidae bivalve family, known to bear endosymbiont bacteria in their gills like Lucinidae (Le Pennec and Beninger, 2000). Bologna (2006) found that the Solemyidae Solemya velum was more abundant at the edges of a Zostera marina meadow than outside and inside the meadow, while Tanner (2005) observed that Solemyidae, like other bivalve families, were homogeneously distributed between edge and centre of $Z$. macronuta or $Z$. muelleri meadows.

Our study identified a negative edge effect for the abundance of small individuals, while abundance distribution of large specimens was homogeneous between edge and inner part of the eelgrass meadow. Four mechanisms have been identified to explain changes in organismal abundance patterns across habitat edges: (i) ecological flows, involving the movement of material, organisms or energy between patches; (ii) increased access to multiple habitats and resources; (iii) resource distribution and (iv) species interactions. Edges are maximally exposed to ecological flows and facilitate mobile animals to gain access to resources from different habitats, while resource distribution, competition and predation can be different from the inner part of the same habitat and adjacent habitats (Ries et al., 2004). In seagrass meadows, edges are boundary habitats between bare and vegetated sediments, where water flow slows down and there is increased deposition of organic material and larvae suspended in the water column (Bologna and Heck, 2002). Predation risk 
can also increase because mobile predators seeking refuge and food in seagrass meadows find prey more easily at the edges than in the inner portion of the seagrass (Bell et al., 2001, Peterson et al., 2001, Tanner, 2005, Smith et al., 2008). Differential abundance patterns for bivalves can therefore result from the complex interplay between larval settlement, food availability and predation risk (Bologna and Heck, 1999, 2000, Tanner, 2005, Bologna, 2006, Carroll et al., 2012). The homogenous abundance pattern of the bay scallop Argopecten irradians in artificial Zostera meadows, for instance, resulted from increased post-settlement predation, which counteracted the augmented larval settling at the edges (Carroll et al., 2012). This species abundance instead increased at the edge of the turtle grass Thalassia testudinum, because increased food availability enhanced growth rate and recruitment of juveniles to adult size-classes (Bologna and Heck, 1999).

Decreased abundance of small Loripes could indicate post-settlement predation. In the study area, there are numerous fish that feed on benthic invertebrates and preferentially on suspension-feeding bivalves, such as the gilthead seabream Sparus aurata, the sand smelt Atherina boyeri and the common goby Pomastochistus microps (Zainuri, 1993, Villeger et al., 2012). Furthermore, the mismatch between the abundance pattern of small and large animals could indicate a positive edge effect on juvenile growth rate, probably related to diet shift and suspended food availability, as found for some facultative suspension feeder bivalves (Herman et al., 1999, Rossi et al., 2004, Rossi and Middelburg, 2011). At the edges small Loripes showed a higher degree of mixotrophy, assimilating more suspended food than inside the meadow. For endosymbiont-bearing bivalves, suspended food is energetically more valuable than bacteria and suspension feeding can increase growth rate and reproduction success (Le Pennec and Beninger, 2000, van Gils et al., 2012).

Moreover, the linear relationship between isotopic signature and Loripes size could indicate sizerelated physiological or environmental constraints that narrow the acquisition of certain food sources for small sizes, as found for other facultative suspension feeding benthic consumers (Hentschel, 1998, Rossi et al., 2004). For L. lacteus, these constraints might be related to the progressive increment in the size of gills and the foot. Endosymbiont-bearing bivalves need extremely large gills to maintain an adequate flow of sulphide and oxygen and accommodate large symbiotic populations, while large and extensible foots are fundamental to mine sulphides and collect oxygen from the surface, while remaining buried into the sediment (Scott, 2005, van der Heide et al., 2012).

The diet shift indicated by isotopic signatures appeared of relatively small importance, especially for carbon (10 and $30 \%$ of assimilated carbon and nitrogen, respectively). It is however worthy to consider that natural abundance of stable isotopes taken during one-off sampling, as in this study, could underestimate the real diet shift of $L$. lacteus and that nitrogen was probably a more realistic estimate than carbon. Heterotrophic carbon is more rapidly assimilated and respired than bacterial carbon in symbiont-bearing organisms to support basal metabolism or released as dissolved organic carbon (Pile and Young, 1999). Conversely, the nitrogen derived from suspension feeding is used to provide certain polyunsaturated fatty acids vital for marine bivalves and can be traced in the tissues for longer periods than carbon (Conway et al., 1989, Krueger et al., 1992, Fullarton et al., 1995).

Depending on nutritional requirements, the size of the host and environmental changes, there can be changes in the supply of sulphides necessary for bacterial chemosynthesis, which may alter bacterial growth and cell size (Dufour and Felbeck, 2006, Caro et al., 2007, 2009). One might, therefore, expect differences in the functional parameters of endosymbiont bacteria that indicate variations in cell size and nucleic acid content (SSC and FL1) between the edge and inner part of the eelgrass patches for small specimens of Loripes. In contrast to this hypothesis, the relative bacterial cell size and the nucleic acid content did not vary following the position of the host within seagrass patches. The 
observed diet shifts seemed thus insufficient to stimulate a response in symbiont populations. Moreover, endosymbiont parameters showed small-scale variability that might reflect micro-scale patterns of variability in sulphides as related to seagrass roots and rhizomes. At the root and rhizome interface with the sediment, there is a subtle interplay between sulphide availability and below-ground oxygen diffusion, which can enhance plant survival during anoxic events (Borum et al., 2005). Unfortunately, we were unable to measure sulphide levels in the sediment and we could not prove whether the presence of roots could change sulphide availability and as a consequence the population of endosymbionts, but this might be an important issue that further work could explore.

In conclusion, this study showed clear edge effects on the population structure of the lucinid bivalve $L$. lacteus and, to a minor extent, on its feeding behaviour. Bacteria were always important for the nutrition of Loripes, but small individuals assimilated more heterotrophic carbon and nitrogen when they were at the eelgrass edge. Differential population structure and feeding mode of this endosymbiont-bearing bivalve might have important consequences for the transfer of bacterial carbon and nitrogen to the food web.

\section{Acknowledgements}

The authors wish to thank Patrice Got for its support in cytometric analyses. This work was partly supported by the EC2CO funded project "Le Cycle du carbone dans les réseaux trophiques des Herbiers face à l' Augmentation de la tempeRature et des sels nutritifs dans les lagunes Méditerranéennes (CHARM)" attributed to FR.

\section{References}

Bachelet, G., de Montaudouin, X., Auby, I., Labourg, P.J., 2000. Seasonal changes in macrophyte and macrozoobenthos assemblages in three coastal lagoons under varying degrees of eutrophication. ICES J. Mar. Sci. 57, 1495-1506.

Bell, S.S., Brooks, R.A., Robbins, B.D., Fonseca, M.S., Hall, M.O., 2001. Faunal response to fragmentation in seagrass habitats: implications for seagrass conservation. Biol. Cons. 100, 115-123.

Bologna, P.A.X., 2006. Assessing within habitat variability in plant demography, faunal density, and secondary production in an eelgrass (Zostera marina L.) bed. J. Exp. Mar. Biol. Ecol. 329, 122-134.

Bologna, P.A.X., Heck, K.L., 1999. Differential predation and growth rates of bay scallops within a seagrass habitat. J. Exp. Mar. Biol. Ecol. 239, 299-314.

Bologna, P.A.X., Heck, K.L., 2000. Impacts of seagrass habitat architecture on bivalve settlement. Estuaries 23, 449-457.

Bologna, P.A.X., Heck, K.L., 2002. Impact of habitat edges on density and secondary production of seagrass-associated fauna. Estuaries 25, 1033-1044. 
Borum, J., Pedersen, O., Greve, T.M., Frankovich, T.A., Zieman, J.C., Fourqurean, J.W., Madden, C.J., 2005. The potential role of plant oxygen and sulphide dynamics in die-off events of the tropical seagrass, Thalassia testudinum. J. Ecol. 93, 148-158.

Bostrom, C., Jackson, E.L., Simenstad, C.A., 2006. Seagrass landscapes and their effects on associated fauna: A review. Estuar. Coast. Shelf Sci. 68, 383-403.

Carlier, A., Pascal Riera, P., Amouroux, J.-M., Bodiou, J.-Y., Desmalades, M., Grémare, A., 2009. Spatial heterogeneity in the food web of a heavily modified Mediterranean coastal lagoon: stable isotope evidence. Aquatic Biology 5, 167-179.

Caro, A., Got, P., Bouvy, M., Troussellier, M., Gros, O., 2009. Effects of long-term starvation on a host bivalve (Codakia orbicularis, Lucinidae) and its symbiont population. Appl. Environ. Microbiol. 75(10), 3304-3313.

Caro, A., Gros, O., Got, P., De Wit, W., Troussellier, M., 2007. Characterization of the population of the sulfur-oxidizing symbiont of Codakia orbicularis (Bivalvia, Lucinidae) by single cell analyses. Appl. Environ. Microbiol. 73(7), 2101-2109.

Carroll, J.M., Furman, B.T., Tettelbach, S.T., Peterson, B.J., 2012. Balancing the edge effects budget: bay scallop settlement and loss along a seagrass edge. Ecology 93, 1637-1647.

Cavanaugh, C.M., 1983. Symbiotic chemoautotrophic bacteria in marine invertebrates from sulphiderich habitats. Nature 302, 58-61.

Cavanaugh, C.M., McKiness, Z.P., Newton, I.L.G., Stewart, F.J., 2006. Marine chemosythetic Symbioses. Prokaryotes 1, 475-507.

Conway, N., Capuzzo, J.M., Fry, B., 1989. The role of endosymbiotic bacteria in the nutrition of Solemya velum: evidence from a stable isotope analysis of endosymbionts and host. Limnol. Oceanogr. 34, 249-255.

Crawley, M.J., 2007. The R book. John Wiley \& Sons, UK.

Dando, P., Spiro, B., 1993. Varying nutritional dependence of the thyasirid bivalves Thyasira sarsi and $T$. equalis on chemoautotrophic symbiotic bacteria, demonstrated by isotope ratios of tissue carbon and shell carbonate. Mar. Ecol. Prog. Ser. 92, 151-158.

Dufour, S.C., Felbeck, H., 2006. Symbiont abundance in thyasirids (Bivalvia) is related to particulate food and sulphide availability. Mar. Ecol. Progr. Ser. 320,185-194.

Duplessis, M.R., Dufour, S.C., Blankenship, L.E., Felbeck, H., Yayanos, A.A., 2004. Anatomical and experimental evidence for particulate feeding in Lucinoma aequizonata and Parvilucina tenuisculpta (Bivalvia: Lucinidae) from the Santa Barbara Basin. Mar. Biol. 145, 551-561.

Felbeck, H., Childress, J.J., Somero, G.N., 1981. Calvin-Benson cycle and sulphide oxidation enzymes in animals from sulphide-rich habitats. Nature 293, 291-293. 
Fisher, C.R. 1990. Chemoautotrophic and methanotrophic symbioses in marine invertebrates. Rev. Aquat. Sci. 2, 399-436.

Fry, B., 2008. Stable isotope ecology. Springer, USA.

Fullarton, J.G., Wood, A.P., Sargent, J.R., 1995. Fatty-acid composition of lipids from sulfur-oxidizing and methylotrophic bacteria from thyasirid and lucinid bivalves. J. Mar Biol. Ass. UK 75, 445-454.

Heck, K.L., Hays, G., Orth, R.J., 2003. Critical evaluation of the nursery role hypothesis for seagrass meadows. Mar. Ecol. Progr. Ser. 253, 123-136.

Hentschel, B.T., 1998. Intraspecific variations in delta-13C indicate ontogenetic diet changes in deposit-feeding polychaetes. Ecology 79,1357-1370.

Hentschel, U., Millikan, D., Arndt, C., Cary, S., Felbeck, H., 2000. Phenotypic variations in the gills of the symbiont-containing bivalve Lucinoma aequizonata. Mar. Biol. 136, 633-643.

Herman, P.M.J., Middelburg, J.J., Van de Koppel, J., Heip, C.H.R., 1999. Ecology of estuarine macrobenthos. Adv. Ecol. Res. 29, 195-240.

Herry, A., Diouris, M., Le Pennec, M., 1989. Chemoautotrophic symbionts and translocation of fixed carbon from bacteria to host tissues in the littoral bivalve Loripes lucinalis (Lucinidae). Mar. Biol. 101, 305-312.

Honkoop, P.J.C., Berghuis, E.M., Holthuijsen, S., Lavaleye, M.S.S., Piersma, T., 2008. Molluscan assemblages of seagrass-covered and bare intertidal flats on the Banc d'Arguin, Mauritania, in relation to characteristics of sediment and organic matter. J. Sea Res. 60, 235-243.

Johnson, M.A., Fernandez, C., 2001. Bacterial symbiosis in Loripes lucinalis (Mollusca: Bivalvia) with comments on reproductive strategy. J. Mar. Biol. Assoc. U.K. 81, 251-257.

Johnson, M.A., Fernandez, C., Pergent, G., 2002. The ecological importance of an invertebrate chemoautotrophic symbiosis to phanerogam seagrass beds. Bull. Mar. Sci. 71, 1343-1351.

Krueger, D.M., Gallager, S.M., Cavanaugh, C.M., 1992. Suspension feeding on phytoplankton by Solemya velum, a symbiont-containing clam. Mar. Ecol. Prog. Ser. 86, 145-151.

Le Pennec, M., Beninger, P.G., 2000. Reproductive characteristics and strategies of reducing-system bivalves. Comp. Biochem. Phys. A. 126, 1-16.

Levin, L.A., Michener, R.H., 2002. Isotopic evidence for chemosynthesis-based nutrition of macrobenthos: The lightness of being at Pacific methane seeps. Limnol. Oceanogr. 47, 1336-1345.

Marie, D., Partensky, F., Jacquet, S., Vaulot D., 1997. Enumeration and cell cycle analysis of natural populations of marine picoplankton by flow cytometry using the nucleic acid stain SYBR green I. Appl. Environ. Microbiol. 63, 186-193.

McLeod, R.J., Wing, S.R., 2007. Hagfish in the New Zealand fjords are supported by chemoautotrophy of forest carbon. Ecology 88, 809-816. 
McLeod, R.J., Wing, S.R., 2009. Strong pathways for incorporation of terrestrially derived organic matter into benthic communities. Estuar. Coast. Shelf Sci. 82, 645-653.

McLeod, R.J., Wing, S.R., Skilton, J.E., 2010. High incidence of invertebrate-chemoautotroph symbioses in benthic communities of the New Zealand fjords. Limnol. Oceanogr. 55, 2097-2106.

Peterson, B.J., Thompson, K.R., Cowan, J.H., Heck, K.L., 2001. Comparison of predation pressure in temperate and subtropical seagrass habitats based on chronographic tethering. Mar. Ecol. Progr. Ser. 224, 77-85.

Pile, A., Young, C., 1999. Plankton availability and retention efficiencies of cold-seep symbiotic mussels. Limnol. Oceanogr. 44, 1833-1839.

Reynolds, L.K., Berg, P., Zieman, J.C., 2007. Lucinid clam influence on the biogeochemistry of the seagrass Thalassia testudinum sediments. Estuar. Coast. 30, 482-490.

Ries, L., Fletcher, R.J., Battin, J., Sisk, T.D., 2004. Ecological responses to habitat edges: Mechanisms, models, and variability explained. Annu. Rev. Ecol. Evol. Syst. 35, 491-522.

Rossi, F., Middelburg, J.J., 2011. Intraspecific diet shift of Macoma balthica during community reassembly in an estuarine intertidal flat. Est. Coast. Shelf Sci. 92, 496-501.

Rossi, F., Herman, P.M.J., Middelburg, J.J., 2004. Interspecific and intraspecific variation of delta C-13 and delta $\mathrm{N}-15$ in deposit- and suspension-feeding bivalves (Macoma balthica and Cerastoderma edule): Evidence of ontogenetic changes in feeding mode of Macoma balthica. Limnol. Oceanog. 49, 408-414.

Schweimanns, M., Felbeck, H., 1985. Significance of the occurrence of chemoautotrophic bacterial endosymbionts in lucinid clams from Bermuda. Mar. Ecol. Prog. Ser. 24, 113-120.

Scott, K.M., 2005. Allometry of gill weights, gill surface areas, and foot biomass $\delta 13 \mathrm{C}$ values of the chemoautothroph-bivalve symbiosis Solemya velum. Mar. Biol. 147, 935-941.

Smith, T.M., Hindell, J.S., Jenkins, G.P., Connolly, R.M., 2008. Edge effects on fish associated with seagrass and sand patches. Mar. Ecol. Progr. Ser. 359, 203-213.

Spiro, B., Greenwood, P., Southward, A., Dando, P., 1986. 12C/13C ratios in marine invertebrates from reducing sediments: confirmation of nutritional importance of chemoautotrophic endosymbiotic bacteria. Mar. Ecol. Prog. Ser. 28, 233-240.

Stewart, F.J., Newton, I.L.G., Cavanaugh, C.M., 2005. Chemosynthetic endosymbioses: adaptations to oxic-anoxic interfaces. Trends Microbiol. 13, 439-448.

Tanner, J.E., 2005. Edge effects on fauna in fragmented seagrass meadows. Austral Ecol. 30, 210218.

Taylor, J.D., Glover, E.A., 2006. Lucinidae (Bivalvia): the most diverse group of chemosymbiotic molluscs. Zool. J. Linn. Soc. 148, 421-438. 
Troussellier, M., Courties, C., Lebaron, P., Servais, P., 1999. Flow cytometry discrimination of bacterial population in seawater based on Syto 13 staining of nucleic acids. FEMS Microb. Ecol. 29, 319-330.

Underwood, A.J., 1997. Experiments in Ecology: Their logical design using analysis of variance. Cambridge University Press, UK.

van der Heide, T., Govers, L.L., de Fouw, J., Olff, H., van der Geest, M., van Katwijk, M.M., Piersma, T., van de Koppel, J., Silliman, B.R., Smolders, A.J.P., van Gils, J.A., 2012. A Three-Stage Symbiosis Forms the Foundation of Seagrass Ecosystems. Science 336, 1432-1434.

van Gils, J.A., van der Geest, M., Jansen, E.J., Govers, L.L., de Fouw, J., Piersma, T., 2012. Trophic cascade induced by molluscivore predator alters pore-water biogeochemistry via competitive release of prey. Ecology 93, 1143-1152.

Villeger, S., Ferraton, F., Mouillot, D., de Wit, R., 2012. Nutrient recycling by coastal macrofauna: intra- versus interspecific differences. Mar. Ecol. Progr. Ser. 452, 297-303.

Zainuri, M., 1993. Structure des peuplements ichtyologiques d'une zone d'herbiers à Zostera marina de l'étang de Thau (France). Etude de la composition alimentaire des juvéniles de loup (Dicentarchus labrax, Linnaeus, 1758), de la daurade (Sparus aurata, Linnaeus, 1758) et du muge (Chelon labrosus, Risso, 1826) par des approches expérimentales. Phd thesis, Univ. Montpellier 2, France.

\section{Tables}

Table 1. (a) Analyses of variance for the abundance of Loripes lacteus size-classes. Data are not transformed. Significant values relevant for the interpretation of results are in bold. (b) Mean $( \pm S E, n=20)$ individuals core $^{-1}$ at each position (Inner part and Edge) in eelgrass patches. Data were an average of all locations and patches.

\begin{tabular}{|c|c|c|c|c|c|c|c|}
\hline (a) & & \multicolumn{3}{|c|}{ Size-class I } & \multicolumn{2}{c|}{ Size-class II } & \multicolumn{2}{c|}{ Size-class III } \\
\hline & d.f. & MS & F & MS & F & MS & F \\
\hline Location = L & 1 & 46.22 & 10.68 & 409.60 & 1.82 & 0.03 & 0.001 \\
\hline Position = P & 1 & 165.32 & $\mathbf{9 . 1 0}$ & 280.90 & $\mathbf{5 . 4 4}$ & 11.03 & 1.33 \\
\hline Patch (L) = Pa & 2 & 4.32 & 0.05 & 225.25 & 4.36 & 18.22 & 2.20 \\
\hline${ }^{\mathrm{P}} \mathrm{L} \times \mathrm{P}$ & 1 & 46.22 & & 10.00 & & 0.03 & \\
\hline${ }^{\mathrm{P}}$ Pa $\times$ P & 2 & 27.43 & & 40.05 & & 8.54 & \\
\hline Residual & 32 & 88.85 & & 53.65 & & & \\
\hline \multicolumn{7}{|c|}{ P $=$ Pooling } \\
\hline
\end{tabular}

\begin{tabular}{|c|c|c|c|}
\hline (b) & Size-class I & Size-class II & Size-class III \\
\hline Inner part & $13.1 \pm 1.9$ & $11.6 \pm 1.1$ & $5.4 \pm 0.8$ \\
\hline Edge & $4.3 \pm 2.1$ & $6.3 \pm 0.9$ & $4.3 \pm 0.7$ \\
\hline
\end{tabular}


Table 2 Analyses of variance for the isotopic signatures of Loripes lacteus size-classes. Data for $\delta^{15} \mathrm{~N}$ values of size-class I are log-transformed. Significant values relevant for the interpretation of results are in bold.

\begin{tabular}{|c|c|c|c|c|c|c|c|c|c|c|c|c|c|}
\hline & \multirow[b]{3}{*}{ d.f. } & \multicolumn{6}{|c|}{$\delta^{13} \mathrm{C}$} & \multicolumn{6}{|c|}{$\delta^{15} \mathrm{~N}$} \\
\hline & & \multicolumn{2}{|c|}{ Size-class I } & \multicolumn{2}{|c|}{ Size-class II } & \multicolumn{2}{|c|}{ Size-class III } & \multicolumn{2}{|c|}{ Size-class I } & \multicolumn{2}{|c|}{ Size-class II } & \multicolumn{2}{|c|}{ Size-class III } \\
\hline & & MS & $\mathrm{F}$ & MS & $\mathrm{F}$ & MS & $\mathrm{F}$ & MS & $\mathrm{F}$ & MS & $\mathrm{F}$ & MS & $\mathrm{F}$ \\
\hline Location $=\mathrm{L}$ & 1 & 5.28 & 5.71 & 0.26 & 0.46 & 0.56 & 0.31 & 0.04 & 0.13 & 13.56 & 2.65 & 0.32 & 0.08 \\
\hline Position $=\mathrm{P}$ & 1 & 4.56 & 13.54 & 4.46 & 14.99 & 0.23 & 0.36 & 0.71 & 5.37 & 0.96 & 0.05 & 0.86 & 0.31 \\
\hline $\operatorname{Patch}(\mathrm{L})=\mathrm{Pa}$ & 2 & 0.93 & 0.08 & 0.56 & 1.89 & 1.81 & 2.87 & 0.28 & 2.08 & 5.12 & 4.49 & 3.91 & 2.33 \\
\hline $\mathrm{L} \times \mathrm{P}$ & 1 & ${ }^{\mathrm{p}} 0.05$ & & ${ }^{\mathrm{P}} 0.02$ & & ${ }^{\mathrm{P}} 0.10$ & & ${ }^{\mathrm{p}} 0.11$ & & 19.81 & 17.36 & 2.77 & 1.65 \\
\hline $\mathrm{Pa} \times \mathrm{P}$ & 2 & ${ }^{\mathrm{p}} 1.66$ & & ${ }^{\mathrm{P}} 0.28$ & & ${ }^{\mathrm{p}} 0.45$ & & ${ }^{\mathrm{p}} 0.17$ & & ${ }^{\mathrm{p}} 0.89$ & & ${ }^{\mathrm{p}} 0.36$ & \\
\hline Residual & 32 & 0.36 & & 0.31 & & & & 0.13 & & 1.16 & & 1.76 & \\
\hline$P=1$ & & & & & & & & & & & & & \\
\hline
\end{tabular}


Fig 1. Relationships between shell size and the isotopic signatures of the muscle tissue of Loripes lacteus for (a) $\delta^{13} \mathrm{C}$ and $(b) \delta^{15} \mathrm{~N}$ at the edge and in the inner part of the eelgrass Nanozostera noltii. Lines indicate significant linear correlations $\left(R^{2}\right.$ are reported for each graph). Equations represent the linear regression of isotopic signature ( $\mathrm{y}$ values) on size ( $\mathrm{x}$ value).

(a)

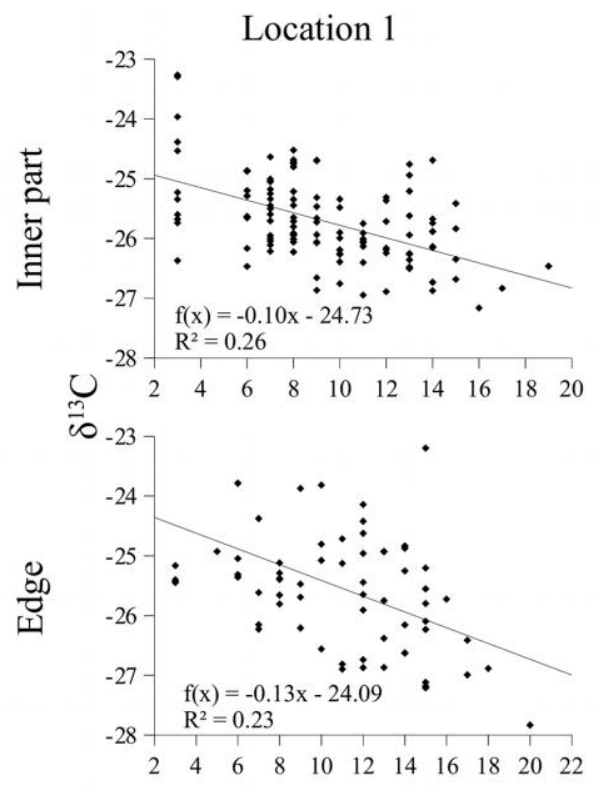

(b)

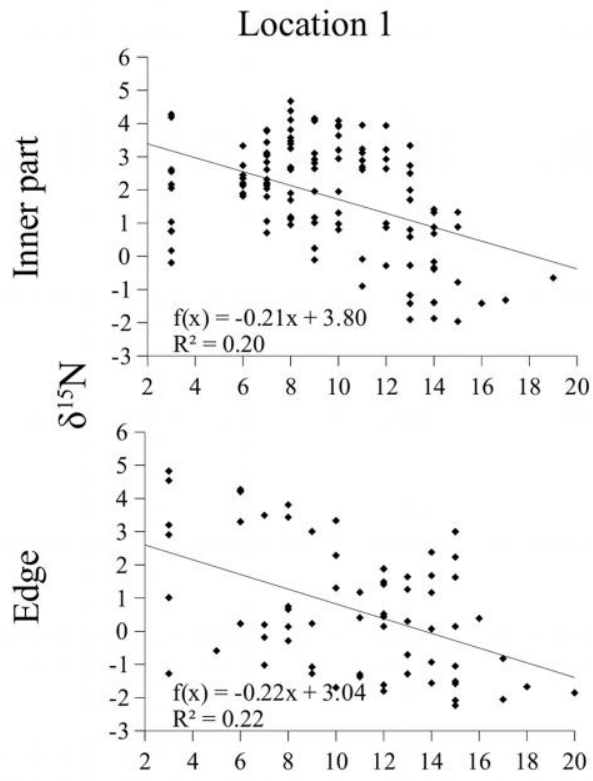

Location 2
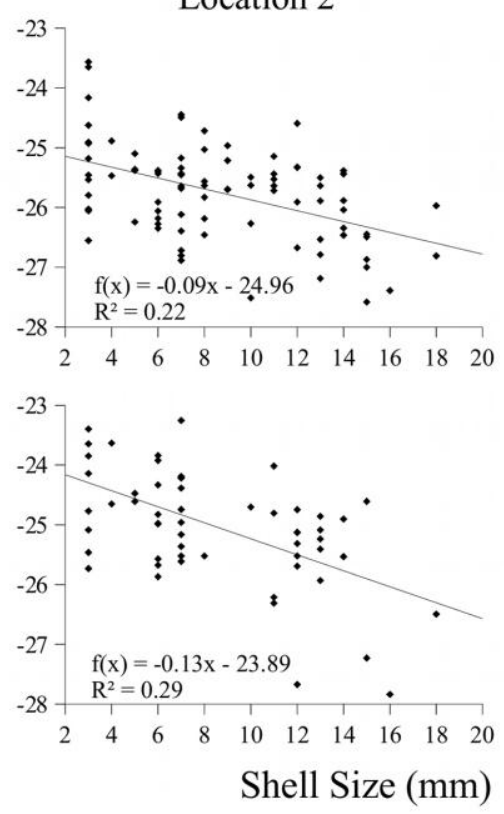

Location 2
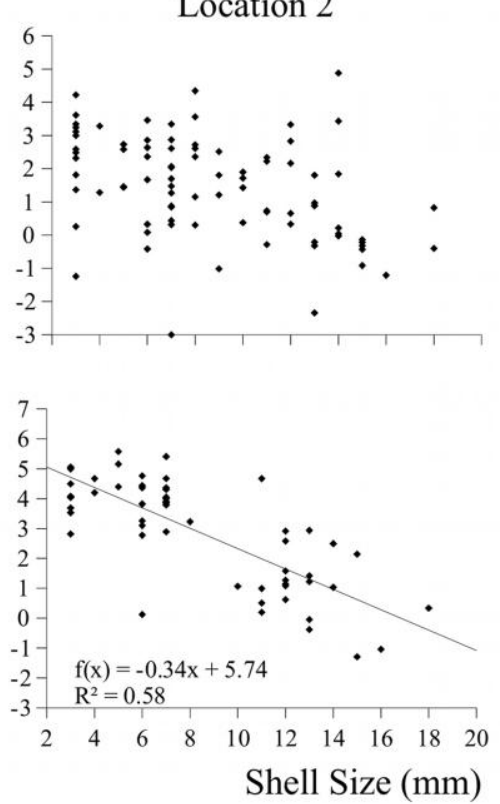
Fig 2. Dual-isotope plot summarizing mean $( \pm S E)$ of $\delta^{13} \mathrm{C}$ and $\delta^{15} \mathrm{~N}$ for the 3 size classes of Loripes lacteus (I, II and III), for the suspension feeder bivalves Cerastoderma glaucum and Venerupis aurea and for consumers feeding on endosymbiotic bacteria (see Materials and Methods for details). Values are averaged over patches and locations for each position within the eelgrass meadows (edge and inner part).

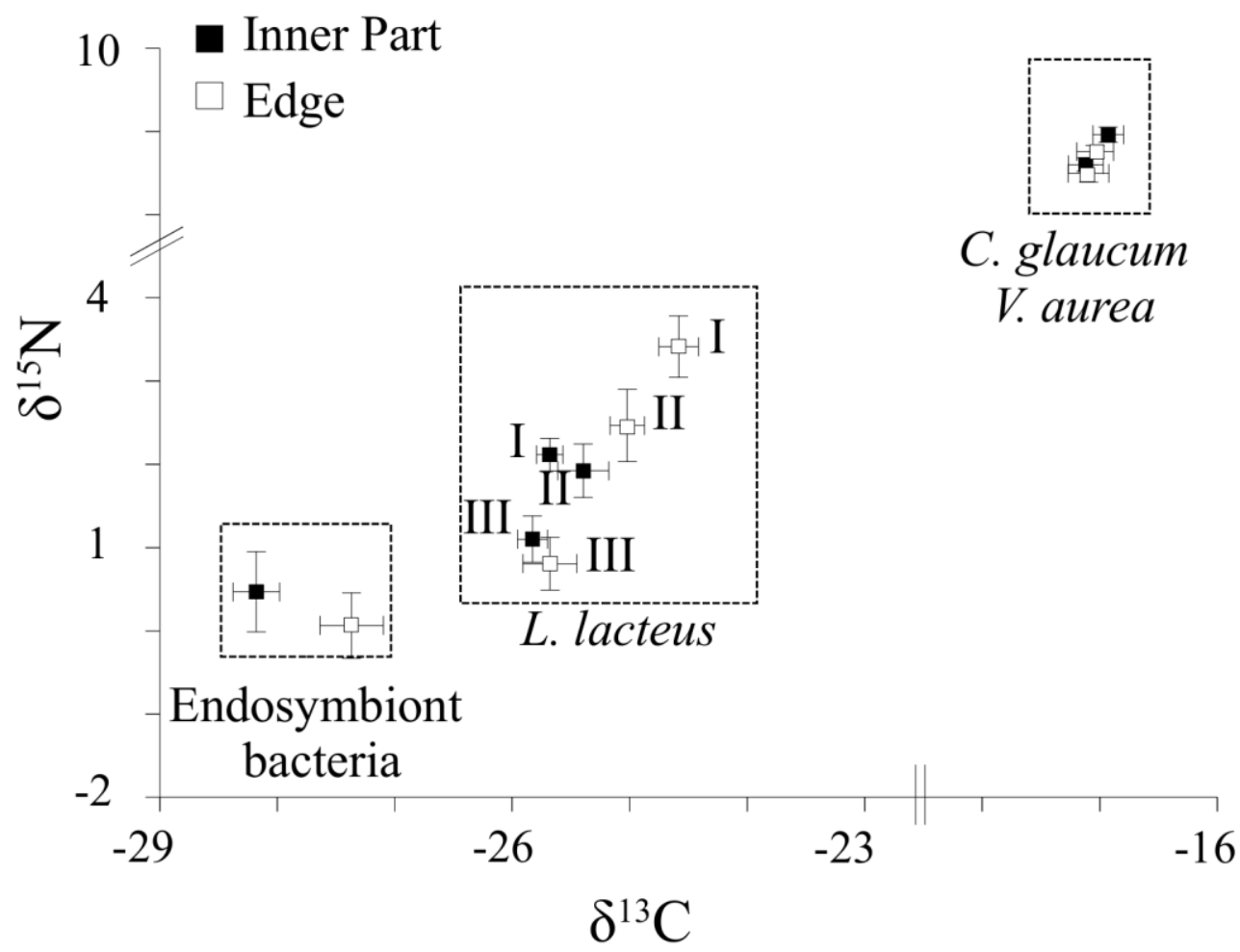


Fig 3. Estimated percentages (Mean+SE) for bacterial carbon and nitrogen contribution to Loripes lacteus diet for each size class in the inner part and at the edge of eelgrass patches. Values are averaged over patches and locations.
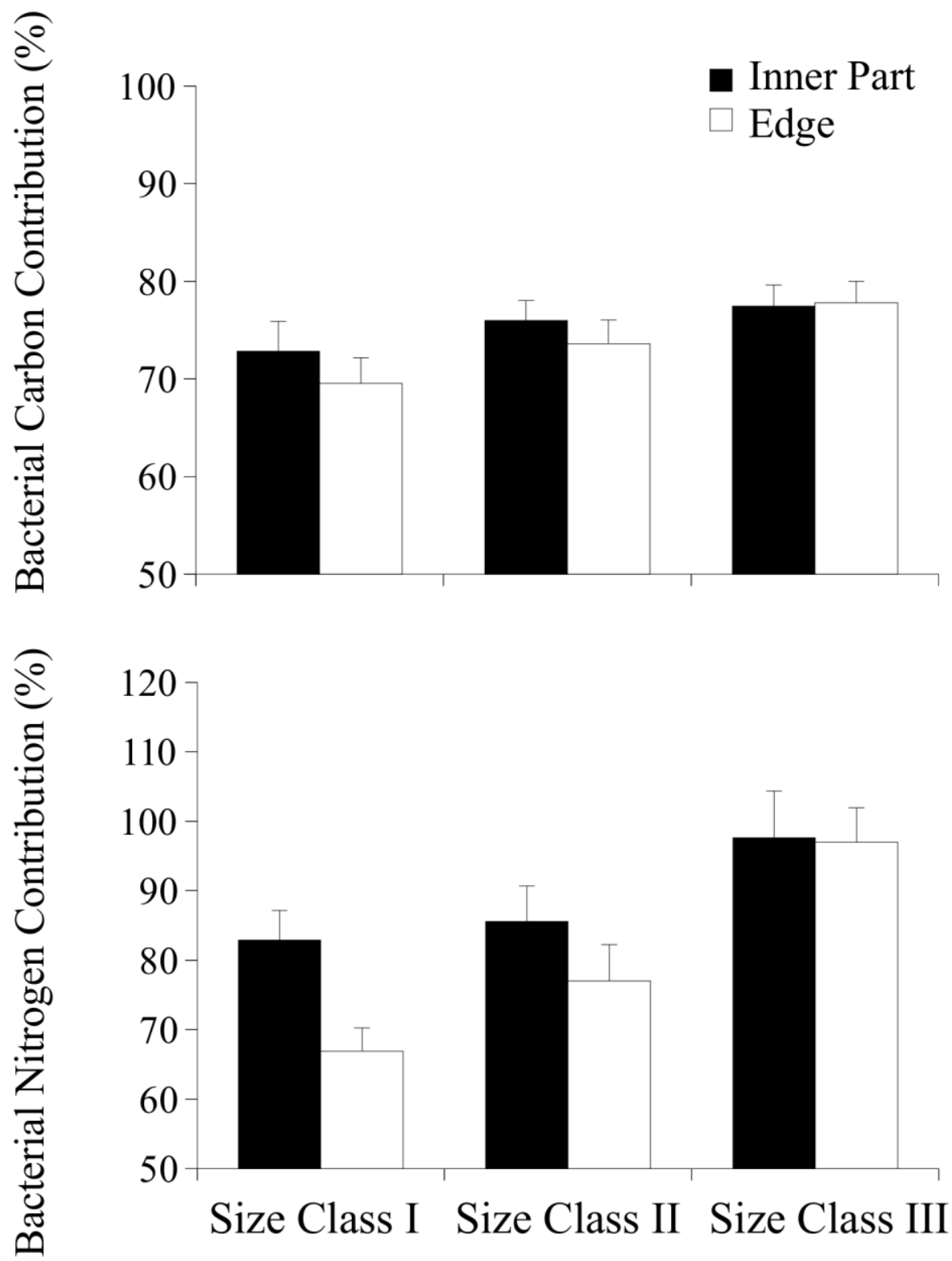
Fig 4. (a) Example of a dot plot representation for the flow cytometer analysis of the symbiotic population hosted by the gills of Loripes lacteus. (b) Mean ( $\pm S E$ ) normalised average values for endosymbiotic bacteria parameters SSC and FL1 as calculated from each flow cytometer analysis for each location, position (edge vs. inner part) and size class. Values are averaged over patches.

(a)

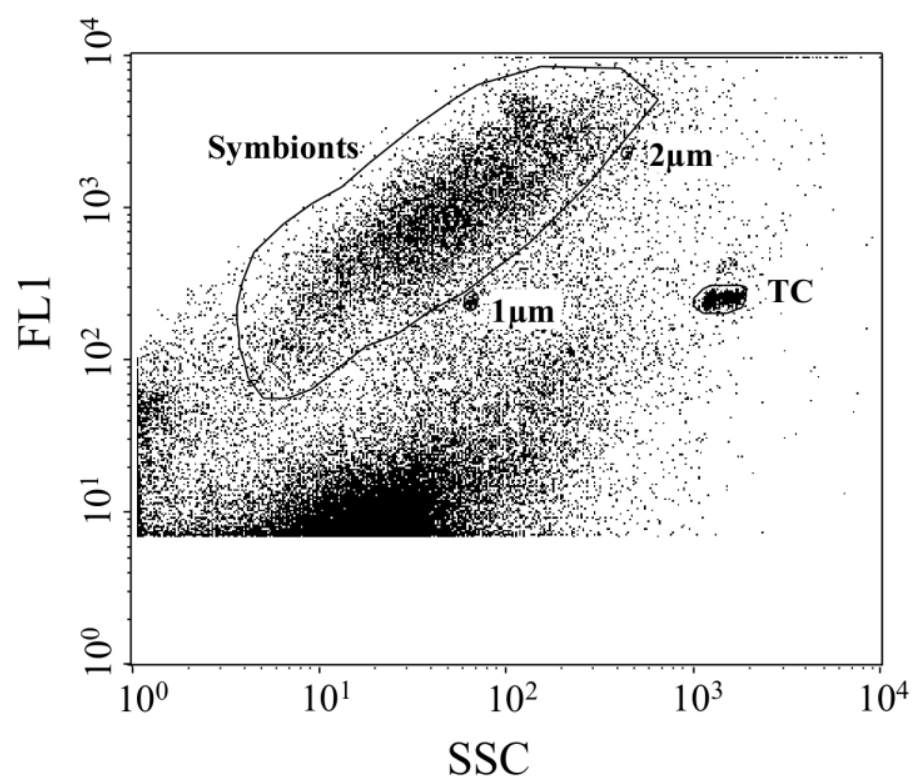

(b)

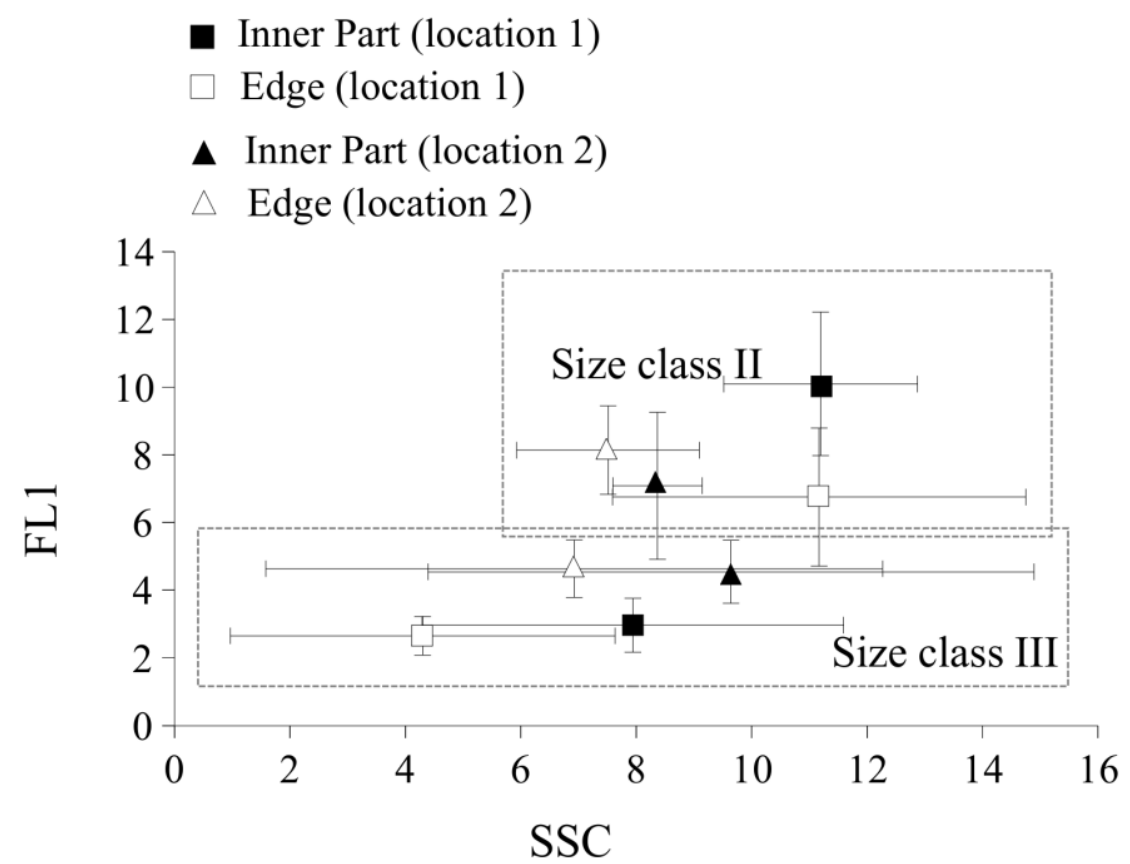

